\title{
Inguinal hernia repair with local anesthesia in the outpatient
}

\section{Herniorrafia inguinal com anestesia local em regime ambulatorial}

\author{
Flavio Antonio de Sá Ribeiro, tCbC- RJ 1; Fernanda Padron 2; Tiago Duarte Magalhães Castro3; \\ lucio Carlos de Azevedo Torres Filho ${ }^{4}$; Baltazar de Araujo Fernandes, TCBC-RJ ${ }^{5}$
}

A B S T R A C T

\begin{abstract}
Objective: To demonstrate the feasibility of inguinal hernia repair with local anesthesia in an outpatient regime, with safety, efficacy and short learning curve. Methods: We prospectively evaluated 454 patients undergoing inguinal hernia repair under local anesthesia on an outpatient basis between November 2004 and August 2008. Of the total number of hernias surgically treated in this period, 285 were operated on the right, 163 on the left and six bilateral. We used clinical, surgical and psychosocial criteria for inclusion in the procedure. The parameters for exclusion were complex, irreducible or recurrent hernia, obesity (BMI greater than $30 \mathrm{~kg} / \mathrm{m}^{2}$ ), patient's refusal and psychiatric disorder. All patients underwent elective surgery and were analyzed regarding surgical outcome, complications and hospital stay. Results: All operations were completed successfully. In no case there was need to change the anesthetic method. Surgical time was similar to that conducted with other methods of anesthesia and there wereno cases of adverse effects of local anesthetics. Intra-operative complications amounted to approximately $2.64 \%(12 / 454)$. There was no need for hospital admissions greater than 24 hours. Conclusion: The procedure is feasible and causes no perioperative significant pain, is safe, can be performed by residents under supervision, has satisfactory patient acceptance and complications similar to those observed in a conventional herniorrhaphy, allowing lower time and cost of hospitalization and faster access to treatment.
\end{abstract}

Key words: Inguinal hernia / surgery. Local anesthesia. Ambulatory surgical procedures.

\section{INTRODUCTION}

T he inguinal hernia repair with local anesthesia is widely used around the world ${ }^{1,2}$. In Brazil, even with the encouragement of its use for more than two decades ${ }^{3}$, it is not yet widespread and accepted, despite the benefits observed by several centers of excellence worldwide ${ }^{4,5}$.

Local anesthesia plus sedation applied for this type of surgery is a method with less impact on the function of organs and systems, is safe, effective, easy to perform, with lower incidence of side effects, such as cardiovascular instability, nausea, vomiting or urinary retention, allowing rapid mobilization and resulting in a shorter hospital stay ${ }^{2-6}$, generally less than 24 hours.

The aim of this study is to prove the feasibility of inguinal hernia repair under local anesthesia without admittance, its safety, efficacy and the short learning curve for the beginner general surgery resident.

\section{METHODS}

We analyzed medical records of 454 patients undergoing inguinal hernia repair with local anesthesia on an outpatient basis between November 2004 and August 2008, all operated by the technique of Lichtenstein ${ }^{7,8}$ associated with intravenous sedation in The First Surgical Clinic of Bonsucesso General Hospital, in Rio de Janeiro.

We used a subjective, unidimensional, numerical, eleven-point scale, as proposed by Huskisson in $1974^{9}$, to evaluate the perioperative pain (0 - no pain, 10 - unbearable pain). In the first postoperative outpatient appointment, each patient attributed a value that best represented the intensity of perceived pain during surgery.

The surgical team consisted of two residents (First and second years) in the surgical field, and the staff surgeon supervising the procedure. Another resident, usually of the second year, was responsible for monitoring

Work done at The First Surgical Clinic, Hospital Geral de Bonsucesso, Ministry of Health - Rio de Janeiro, RJ, Brazil.

1. Master's Degree in Surgery, Universidade Geral do Rio de Janeiro - UFRJ, Rio de Janeiro, RJ, Brazil; 2. Resident, First Surgical Clinic, Hospital Geral de Bonsucesso, Rio de Janeiro, RJ, Brazil; 3. Intern, First Surgical Clinic, Hospital Geral de Bonsucesso; Medical School Graduate, Universidade Severino Sombra; 4. Intern, First Surgical Clinic, Hospital Geral de Bonsucesso; Medical School Graduate, Universidade Severino Sombra; 5. Head, General Surgery Service, Hospital Geral de Bonsucesso. 
the patient. The procedure always took place at the main operating room unit, with a standby anesthesiologist present, not necessarily in the operating room, to give support when needed. The activities conducted by residents are defined in the General Surgery Residency Program, approved by the National Committee of Medical Residency ${ }^{10}$.

The criteria for inclusion in the procedure were clinical: lack of uncontrolled comorbidities - up to ASA II and age younger than 70 years; surgical: primary, reducible inguinal hernia and Body Mass Index BMI less than 30kg/ $\mathrm{m}^{2}$; and psychosocial: understanding of the procedure and emotional stability. The exclusion criteria were complex, irreducible or recurrent hernia, obesity (BMI greater than $30 \mathrm{~kg} / \mathrm{m}^{2}$ ) and psychiatric disorder.

During the procedures the patients were monitored with pulse oximetry, cardiac monitoring and noninvasive blood pressure and had a peripheral venous access and $3 \mathrm{l} / \mathrm{min}$ oxygen mask therapy.

We used an intravenous bolus of one to ten $\mathrm{mg}$ of midazolam, $20 \mathrm{mg}$ of tenoxicam, 20 to $100 \mathrm{mg}$ of meperidine and $1 \mathrm{~g}$ of cefazolin. After reaching the desired depth of sedation, we performed the blocking technique of the operative field with an anesthetic solution consisting of $20 \mathrm{ml}$ of $0.75 \%$ ropivacaine, $20 \mathrm{ml}$ of $2 \%$ lidocaine and $0.4 \mathrm{ml}$ of $0,1 \%$ adrenaline dissolved in $30 \mathrm{ml}$ of distilled water, amounting a $70 \mathrm{ml}$ solution.

\section{Blocking technique}

The anesthetic block of the operative field was carried out according to the following steps: marking points on local anesthetic injection (Figure 1) to start the procedure with local anesthetic injection, $10 \mathrm{ml}$ in the iliac spine, $5 \mathrm{ml}$ aiming for the deep ring and superficial femoral innervation; $5 \mathrm{ml}$ in the incision; $5 \mathrm{ml}$ in the pubis and in external oblique aponeurosis (Figure 2), $5 \mathrm{ml}$ directly over the external oblique aponeurosis, aiming for the cord, $5 \mathrm{ml}$ in the pubis after opening the external oblique aponeurosis. One must wait for the latency time of 20 minutes before starting the procedure.

The Learning Curve is evaluated as the time necessary for the first year resident to perform the complete surgical procedure, with domain of the anatomy and technique used and the anesthetic blockade. During this period the Surgical Clinic staff evaluates the conduct of the resident, his/her knowledge and ability to perform the anesthetic blockade and to identify anatomical structures of the inguinal canal, as well as the ease in performing the standard Lichtenstein technique ${ }^{8}$ adopted by the Clinic.

\section{RESULTS}

Of all patients operated, 22 (4.8\%) were female and 432 (95.2\%) male. We performed 285 hernioplasties on the right (62.8\%), $163(35.9 \%)$ on the left and six bilateral $(1.3 \%)$.

With respect to the Nyhus classification, $55 \%$ of cases were classified as type II, 24\% type III-A, 14\% type IIIB and $7 \%$ type I.

All operations were successfully completed. In neither case a change in the anesthetic method was necessary. Operative time ranged between 40 and 90

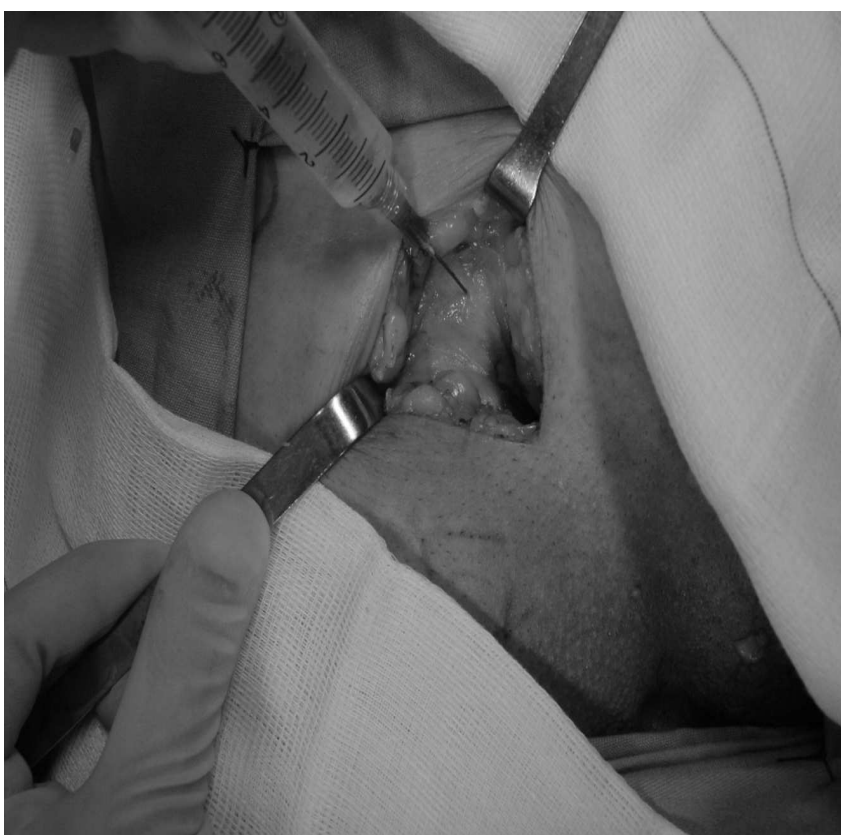

Figura 2 - Before opening the external oblique aponeurosis, more
$5 \mathrm{ml}$ of the anesthetic are injected.

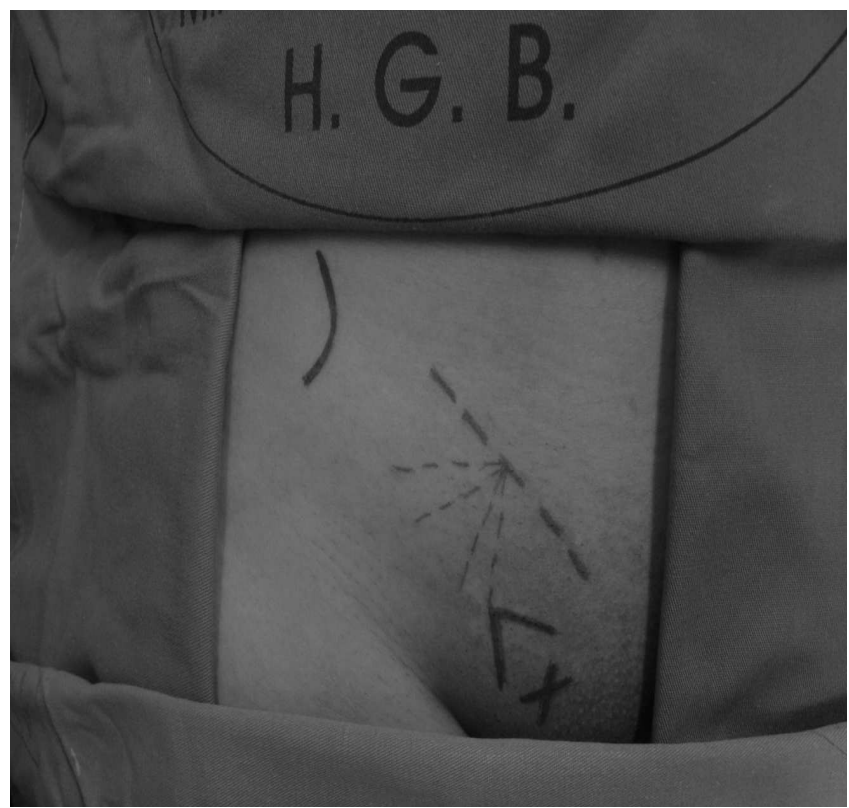

Figura 1 - Antero-superior iliac spine in the upper-left; pubis, inferiorly, over the right and groin; landmarks for the injection of anesthetics. 
minutes, with an average of 65 , with no cases of local anesthetics adverse effects.

There were seven cases needing assistance by the anesthesiologist, with rapid resolution of the problem (perioperative complications): four cases of sedative side effects (agitation), reversed with the use of specific antagonist; three cases of hypotension. There was no need for hospitalization longer than 24 hours.

Regarding the perception of pain, $92 \%$ of patients denied feeling any pain, while $8 \%$ reported some soreness: grade I in six patients, grade II in three, grade III in one and grade IV in two.

When asked about the surgical experience with local anesthesia, all the patients, even those included in the $8 \%$ who reported some soreness, said they were satisfied with the treatment received and, should they develop another medical condition that required surgery, they would agree to be submitted to it with use of local anesthesia.

There were no deaths. Immediate postoperative complications, defined by presentation between the end of the surgery and hospital discharge were: a case of wound bleeding, handled with dressing change, without delay in hospital discharge.

Late postoperative complications, defined as being identified from the first postoperative consultation until the last meeting recorded during the study period, were: five hernia recurrences ( $1 \%)$, the earliest at 6 months and latest after 1 year of follow-up; four cases of chronic pain $(0.9 \%)$; 20 cases of wound infection (subcutaneous), without compromising the prosthesis, or surgical outcome (4.4\%); one graft rejection $(0.2 \%)$; 53 seromas $(12 \%)$ that did not evolve to wound infection; $29(6.4 \%)$ complaints of paresthesia; 35 (8\%) wound hematomas; 13 cases (3\%) of swelling of the surgical scar, without the presence of seroma or infection; 14 cases (3.1\%) of orchitis.

\section{DISCUSSION}

The work of Lichtenstein ${ }^{6}$, developed in his clinic in California, shows 2000 patients operated on by his technique without hospitalization and with local anesthesia with absence of severe complications or deaths, and a recurrence rate below $1 \%$.

In Brazil, the work of Silva ${ }^{11}$ held in Porto Alegre, comparing the conventional outpatient inguinal hernia repair without hospitalization, showed similar complication rates between procedures with and without hospitalization, with costs to the institution $20 \%$ lower. This same study noted the impact in significantly reducing the waiting list, similar to results found in this study. Confirming the impression about this aspect, we mention the work published by Neto ${ }^{12}$, which also consistently emphasizes the presented method.

The regulation of the activity and organization of outpatient surgery units is found in a series of official documents produced by the Brazilian Federal Government, as the RDC $n 50$ resolution dated February $21^{\text {st }}, 2002$, and the various resolutions of the Federal Council of Medicine (CFM resolutions No 1409/94 and No 1802/2006 CFM, and also the resolutions of the Regional Medical Council of Rio de Janeiro No 180/2001 and No. 215/06 with its annexes). Internationally, the World Health Organization ${ }^{13}$ and the International Association for Ambulatory Surgery ${ }^{14}$, based in Belgium, produce large amounts of legal, managerial and technical material to designing and developing programs of outpatient surgery.

As the Program of Outpatient Herniorraphy under local anesthesia is part of the training of young residents in Bonsucesso General Hospital, we expected a degree of difficulty above what was found, with higher recurrence and complication rates, which was not verified. This fact proves that the method is the one with less impact on the function of organs and systems, being safe, effective, easy to perform, yet having a lower cost because the patient is operated without admittance to the institution. There was also a lower incidence of side effects, such as cardiovascular instability, nausea, vomiting or urinary retention. The patient undergoing local anesthesia is rapidly mobilized after surgery, resulting in shorter hospital stay.

Surgical treatment of inguinal hernias is performed in outpatient clinics in about $70 \%$ of patients diagnosed with inguinal hernia in continents such as Europe and North America since the early eighties'. In Brazil, even with the knowledge of this surgical technique and the incentive to use it for more than two decades, it is still little known and accepted, and presented in national publications with an air of novelty and not as a standard².

Keyes published, in $2008^{15}$, a review conducted by the American Association for Accreditation of Ambulatory Surgery Facilities on 1,141,418 surgical procedures performed in multiple ambulatory surgery centers, finding 23 deaths, 13 attributed to embolism by autopsy report; only one case was due to complications of the surgical procedure. The procedure most frequently associated with thromboembolic episodes is the abdominoplasty performed at a day-hospital regime. There are no published reports of deaths resulting from ambulatory hernia operations ${ }^{2}$.

Recently Barros et. al ${ }^{16}$ tried to highlight the reasons or situations where the need for admission (unscheduled) arises and reported the experience of their service in Portugal, with over 6000 cases of ambulatory surgeries, in an attempt to identify risk factors related to unscheduled hospitalization. Those that were statistically significant were: gynecologic procedures, nausea and vomiting, bleeding, severe pain, and duration of anesthesia over 120 minutes. In that work more than $30 \%$ of the procedures were laparoscopic and $40 \%$ were inguinal hernia repairs. The latter had, as an important factor, the occurrence of bleeding from the wound immediately after 
the procedure, approximately $0.2 \%$ of hernia ambulatory operations with local anesthesia.

The need for an effective pathway for the treatment of less complex surgical disorders, of great socioeconomic impact, with the recognition of inguinal hernia as an important public health problem in Brazil, which keeps a very large number of individuals out of their work posts, and the concern about the need to ensure adequate training to our residents, made in 2004, the First Surgical Clinic of Bonsucesso General Hospital develop actions to ensure achievement of these procedures, without, however, compromising the need of beds for more severe patients. In this context, the "Program for surgery under local anesthesia without hospitalization" arose, in which was introduced the surgical treatment of inguinal hernias along with procedures such as: other abdominal hernias, anorectal surgery and surgical treatment of pilonidal cysts. This program was inspired and adapted to the reality of the institution from the successful experience of the outpatient Piquet Carneiro Polyclinic developed at the University of Rio de Janeiro (UERJ).

The lack of resources, the hospital demand focused on high complexity, the care of oncology patients, besides the growing need for organ transplantation, mobilized almost all Bonsucesso General Hospital structure. Even worse, the lack of clear policies for primary care and strong hospital-centered health care "marketing" combine to virtually disable the care of patients with diseases that require a less complex surgery, but of great socioeconomic impact.

The waiting list for surgical treatment of patients with inguinal hernia, which stretches for about five years, is observed in most public health units in Rio de Janeiro, compromising the social and financial spheres of the patients and their families and overwhelming the welfare system.

Inguinal hernias affect a significant percentage of the active population in addition to compromising the quality of life of the population over 60 years old, constituting a major public health problem. These patients search various health care units in pursue of definitive treatment to allow their return to usual activities. In Bonsucesso General Hospital the most immediate result was the end of the waiting list for surgical treatment of inguinal hernia.

The introduction of the project of surgical abdominal wall hernias with local anesthesia without hospitalization, initiated in 2004 by the First Surgical Clinic of the HGB, in accordance with initiative of the then director of the Hospital, Dr. Victor Grabois, who had created the institution's Short Stay Unit, significantly decreased the waiting list, which was of about six years, a reality that still persists in most Brazilian public hospitals.
The program led to a significant improvement in the surgical training of the resident's body and of the HGB interns ${ }^{2}$, going from the 24 hernia operations in 2003 to 240 in 2009.

The first-year residents begin its activities in February (first week day) following the second-year residents in their activities. The initiating residents act as the first assistants in the outpatient procedures. Between May and June they begin to operate and control the entire procedure (surgery itself, local anesthesia, sedation and patient management, monitoring and finally the selection of the patient to be operated) under supervision. On average, they end the year with about 30 hernia operations each.

The second year resident never departs from this activity and at the end of the residence he or she is able to multiply the program where the structure allows and there is political will to do so.

Inguinal hernia results in a barrier to a job for a significant and productive percentage of the population, jeopardizing the patients and their dependents, burdening the State and causing disorder to clinics of hospitals in comings and goings and waiting in lists that can take years.

This work shows that a surgical service of a tertiary hospital focused on oncology of the digestive tract, endocrine and advanced laparoscopic surgery can successfully achieve the implementation of a program of high social impact, responding to the huge demands of its surroundings, without harm to their routine care and the goals of the institution, with hospitalization lasting less than 24 hours, without increasing costs, with maximum productivity, implementing the use of the hospital human resource, optimizing the bed occupancy and improving the training of residents.

Thus, the procedure "Inguinal Hernia Surgery with Local Anesthesia in Outpatient Regime" is feasible, without significant perioperative pain, is safely performed by residents under supervision, enabling a fast and secure learning curve, was well accepted by patients, with complications similar to those observed in a conventional herniorrhaphy, allowing a shorter hospital stay and consequently a lower cost and faster access to treatment, which is also easily replicated elsewhere with a good standby team and minimal resources.

We sincerely hope that other Brazilian services can adopt this safe and more economical mode of treatment, like other countries have already done a few decades ago with widespread success.

The World Health Organization ${ }^{13}$, the British ${ }^{17}$ and Portuguese Health Services have recent publications ${ }^{16,18}$ on their websites encouraging outpatient surgery, making suggestions and supplying algorithms and protocols to facilitate the growth and adoption of these procedures on an outpatient basis. 


\section{R E S U M O}

Objetivo: Comprovar a viabilidade da técnica de herniorrafia inguinal com anestesia local, em regime ambulatorial, com segurança, eficácia e curta curva de aprendizado. Métodos: Analisamos prospectivamente 454 pacientes submetidos à herniorrafias inguinais sob anestesia local em regime ambulatorial entre novembro de 2004 e agosto de 2008. Do total de hérnias tratadas cirurgicamente neste período, 285 foram operadas à direita, 163 à esquerda e seis bilaterais. Foram utilizados critérios clínicos, cirúrgicos e psicossociais para inclusão no procedimento. Os parâmetros para exclusão foram hérnia complexa ou irredutível, hérnia recidivada, obesidade (IMC maior que $30 \mathrm{Kg} / \mathrm{m}^{2}$ ), recusa do paciente e pacientes psiquiátricos. Todos os pacientes foram operados eletivamente e analisados quanto ao resultado cirúrgico, suas complicações e tempo de internação hospitalar. Resultados: Todas as operações foram concluídas com êxito. Em nenhum dos casos foi necessário a mudança do método anestésico. O tempo cirúrgico foi semelhante ao realizado com outros métodos de anestesia, não havendo casos de efeitos adversos dos anestésicos locais. As complicações intra-operatórias totalizaram aproximadamente 2,64\% (12/454) dos casos. Não houve necessidade de internações hospitalares superiores ao período de 24 horas. Conclusão: 0 procedimento é viável sem dor per - operatória significativa, com segurança, podendo ser realizada por residentes sob supervisão, com satisfatória aceitação pelos pacientes, com complicações semelhantes às observadas em uma herniorrafia convencional, possibilitando um tempo e custo de internação menor e acesso mais rápido dos pacientes ao tratamento.

Descritores: Hérnia inguinal/cirurgia. Anestesia local. Procedimentos cirúrgicos ambulatórios.

\section{REFERENCES}

1. Zavadinack Netto M, Prado Filho OR, Bandeira COP, Sales KPF, Camiloti TA. Herniorrafia inguinal: anestesia local ou regional? Acta Scientiarum 22(2);621-623, 2000.

2. Ribeiro FAS. Cirurgia Ambulatorial. In: Saad Junior R, Salles ROR, Carvalho WR, Maia AM, editores. Tratado de Cirurgia do CBC. São Paulo: Atheneu; 2009. p.1467-81.

3. Vater J, Gonçalves MCV. Ampliação do binômio anestesia localpaciente externo: enfoque especial para as hérnias inguinocrurais. Resid. Méd. (RJ).1987; 15(5):10, 13-4, 17-22.

4. Abdu RA. Ambulatory herniorrhaphy under local anesthesia in a community hospital. Am J Surg .1983;145(3):353-6

5. Amid PK, Shulman AG, Lichtenstein IL. Local anesthesia for inguinal hernia repair step-by-step procedure.Ann Surg. 1994;220(6):7357

6. Skinovsky J, Sigwalt MF, Bertinato LP, Chibata M, Moreira LMS, Granzotto PCD. Herniorrafia inguinal com anestesia locorregional - (uso de ropivacaína). Rev Col Bras Cir. 2006;33(4):224-227.

7. Lichtenstein IL. Hernia repair without disability. $1^{\text {st }}$ ed. St. Louis: Mosby; 1970.

8. Sakorafas GH, Halikias I, Nissotakis C, Kotsifopoulos N, Stavrou A, Antonopoulos C, Kassaras G. Open tension free repair of inguinal hernias; the Lichtenstein technique. BMC Surg. 2001;1:3. Epub 2001 Oct 15.

9. Huskisson, E.C. Measurement of pain. Lancet, v.2, n.7889, p.11271131,1974

10. MEC [Internet]. Brasília: Ministério da Educação; c2009. Disponível em: http://www.mec.gov.br

11. Silva DN, Griebeler ML, Fernandes SF, Paixão LQ, Pitrez FAB. Herniorrafia Ambulatorial Comparada a Convencional. Rev. Col. Bras. Cir. 2004;31(5):287-90.

12. Laurino Neto RM, Buchmann AACM, Messias LRR. Tratamento cirúrgico das hérnias inguinais sob anestesia local em ambulatório. Rev Col Bras Cir.2004; 31(2):102-06.
13. Castoro C., Bertinato L., Baccaglini U., Drace C.A., McKee M., with the collaboration of IAAS Executive Committee Members. «Day Surgery: Making it happen». World Health Organization, on behalf of the European Observatory on Health Systems and Policies. 2007

14. Executive Committee of International Association for Ambulatory Surgery; "Ambulatory (Day) Surgery - Suggested International Terminology and Definitions";Paris,2003. Disponível em http:// www.iaas- med.com/joomla/images/stories/uploaded_files/ IAAS_definitions.pdfhttp://www.iaas-med.com/joomla/index.php

15. Keyes GR, Singer R, Iverson RE, McGuire M, Yates J, Gold A, Reed $\mathrm{L}$, Pollack $\mathrm{H}$, Thompson D. Mortality in outpatient surgery. Plast. Reconstr. Surg.; 2008; 122(1): 245-50; discussion 251-3.

16. Barros $\mathrm{F}$ et al. Can we find predictive factors for unplanned overnight admission. Ambulatory Surgery Journal, vol. -14-1, 2008.

17. Department of Health. "Day surgery: Operational guide». August 2002. Dept. of Health publications. London, 2002: Disponível em: http://www.dh.gov.uk/en/Publicationsandstatistics/ Publications/ Publications PolicyAndGuidance/DH_4005487.

18. Lemos P, Regalado A, Soares J, Alves E. A evolução recente da cirurgia ambulatória em Portugal. Resultados do IV Inquérito Nacional. Rev. Port. Cirurgia Ambulatória,2006;7:5-15.

Received 20/10/2009

Accepted for publication 22/12/2009

Conflict of interest: none

Source of funding: none

How to cite this article:

Ribeiro FS, Padron F, Castro TDM, Torres Filho LCA, Fernandes BA. Inguinal hernia repair with local anesthesia in the outpatient. Rev Col Bras Cir. [periódico na Internet] 2010; 37(6). Disponível em URL: http:/ /www.scielo.br/rcbc

Correspondence to:

Flavio Antonio de Sá Ribeiro

E-mail: flavioasribeiro@bol.com.br 